\title{
The Virunga Landscape
}

\section{Chrislain Eric Kenfack}

\section{Introduction}

The Virunga landscape covers a total area of $15155 \mathrm{~km}^{2}$, running from north to south over the borders of the Democratic Republic of the Congo, Rwanda and Uganda. Protected areas make up 56\% of the landscape: Virunga National Park (772 700 ha), Volcanoes National Park (16 000 ha), a 10-km-wide strip of land running alongside the two parks, Sarambwe Reserve (900 ha) and the Rutshuru Hunting Domain (64 200 ha) (Devers and Vande weghe 2007).

The landscape is comprised of three terrestrial ecoregions: the Afroalpine barrens of Rwenzori-Virunga; the Afromontane forest of the Albertine Rift; and the forest-savannah mosaic of the Lake Victoria area. Also present are aquatic ecoregions in the Albertine Rift Mountains, namely Lakes Kivu, Edward, George, Burera, Ruhondo and Victoria, as well as three mountains ranges: Mitumba, Rwenzori and Virunga.
The climate is bimodal, with two rainy seasons (around September-December and March-May), and two dry seasons (around January and July). The annual temperature stays in the range of $20-23^{\circ} \mathrm{C}$, and the elevation is 680-5119 metres.

\section{Population}

The Virunga landscape is home to 2 million urban residents and almost the same number of rural inhabitants, with an average density of 200-300 people/ $\mathrm{km}^{2}$, peaking at 600/ $\mathrm{km}^{2}$ in some areas (Wengamulay 2011). The main ethnic groups are the Nande, Hutu, Tutsi, Hunde and Kumu. Many members of these ethnic groups live in conurbations.

The main activity is subsistence agriculture, with a small minority of people rearing livestock, fishing and hunting, both for consumption and for sale.

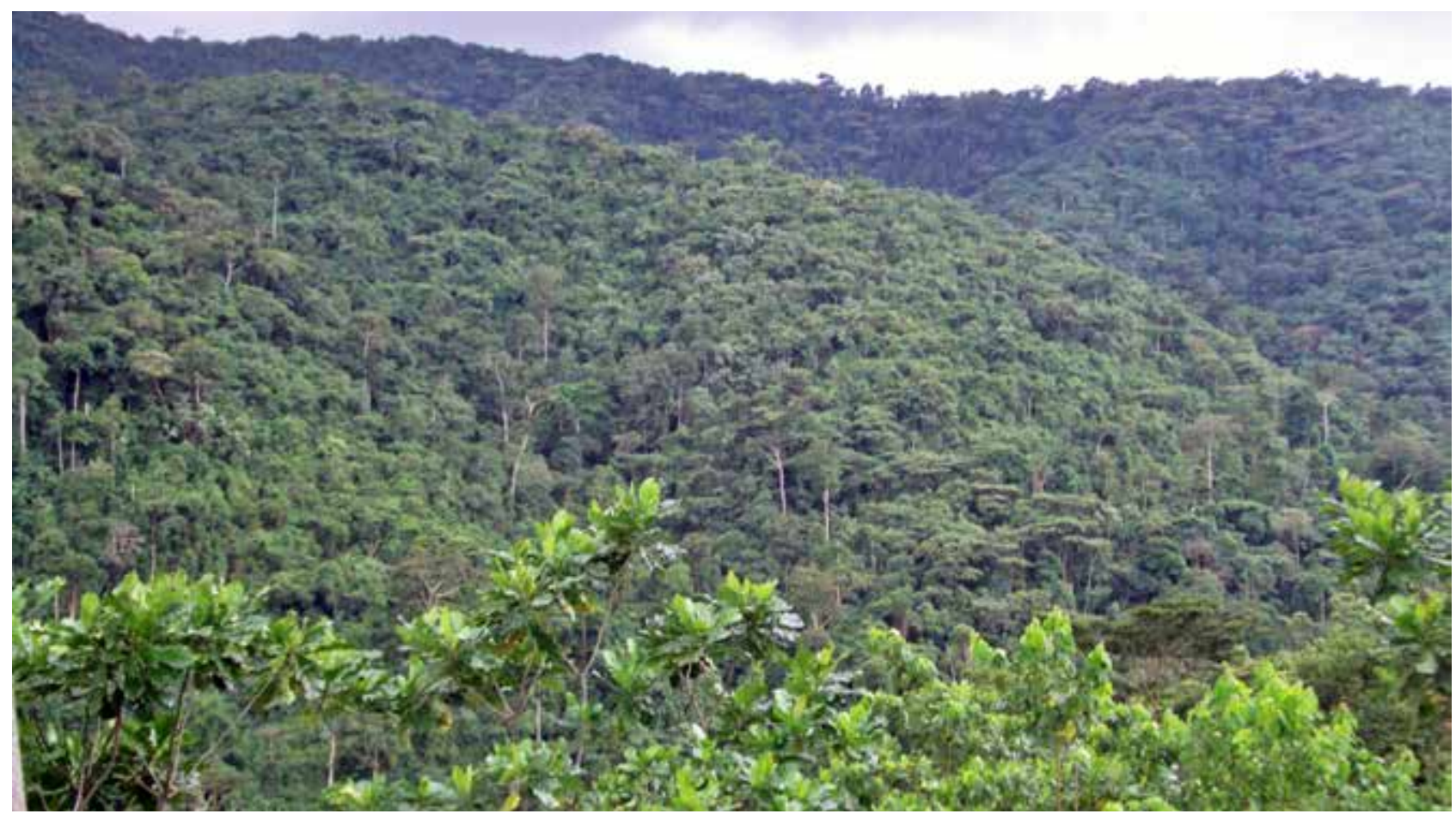




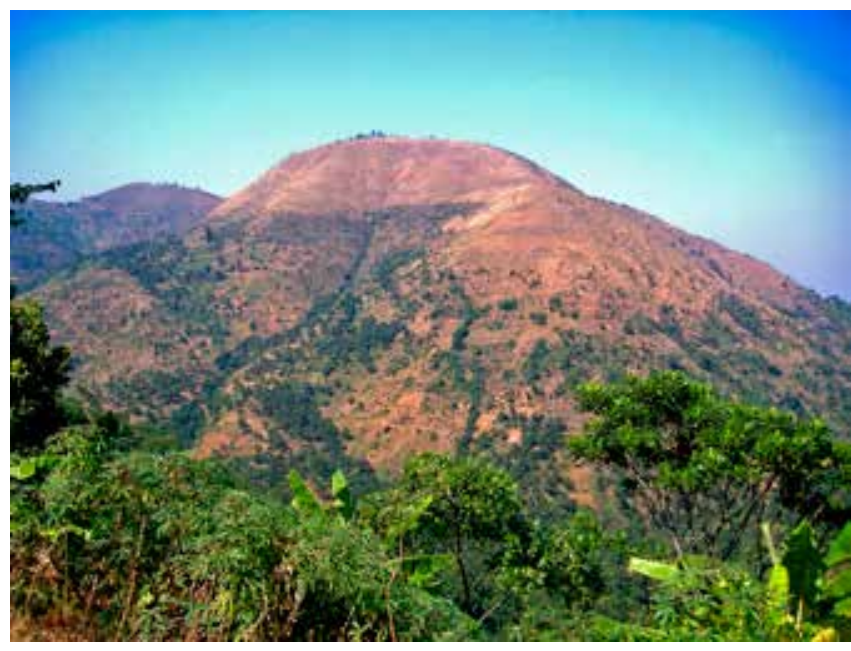

Typical scene in the Virunga landscape, revealing the difficulties of access to land (Photo: Anne Marie Tiani)

\section{Forest surface}

In 2005, forest cover was estimated at $3143 \mathrm{~km}^{2}$ (de Wasseige and Devers 2009).

\section{Vegetation}

The Virunga landscape includes both dense and humid forests, as well as savannahs and agriculture-forest mosaics. The main wooded areas in the northern part of the landscape are in Rwenzori and Semliki and those in the southern part are in the Mikeno, Karisimbi, Gahinga, Sabyinyo, Muhabura, Nyiragongo and Nyamuragira areas; the other areas are mostly savannah.

\section{Deforestation}

An estimated area of $136 \mathrm{~km}^{2}$ of forestland was cleared during 2000-2005, giving a deforestation rate of 4.14\% (de Wasseige and Devers 2009). The main drivers of deforestation are agriculture and the excessive exploitation of wood for energy and for making handicrafts. Furthermore, in 2004, Virunga National Park lost 1500 ha of forest because of the influx of refugees from Rwanda. In Rutshuru Hunting Domain, more than $90 \%$ of the land is totally degraded and used for cultivation (Devers and Vande weghe 2007).

Outside the protected areas, $80 \%$ of the land area is used for subsistence agriculture (crops include maize, Irish potatoes, beans and sorghum) or industrial agriculture (coffee, tea, cacao and cinchona) (de Wasseige and Devers 2009). In addition, wood and charcoal taken from the forest constitute the main sources of energy for local people.

\section{Biodiversity}

The Virunga landscape is home to a great variety of wildlife with exceptional endemism. It has more than 210 species of mammals (although populations are shrinking because of overexploitation and poaching), 706 species of birds, 109 species of reptiles and 78 species of amphibians. In particular among the mammals are 22 species of primates and 3 taxons of great monkeys (de Wasseige and Devers 2009), namely mountain gorillas (Gorilla beringei beringei); Eastern lowland gorillas (Gorilla beringei graueri) and Eastern chimpanzees (Pan troglodytes schweinfurthii).

Also present is a small population of okapis (Okapia johnstoni), mainly in the non-degraded equatorial forest along the Semliki River. This population is threatened by commercial hunting and charcoal production; similarly, a great variety of fishes in Lake Edward are under threat because of overfishing.

\section{Threats to biodiversity conservation}

The main drivers of biodiversity loss are agriculture, pressure on natural resources and poaching.

- Most agricultural techniques are traditional, and productivity is not high enough to meet households' needs. People therefore use more land for farming, thus intensifying the pressure on the forests and leading to about $8 \%$ of the forest lost.

- The pressure on natural resources is evident in the overfishing, overexploitation of land and overexploitation of flora and fauna. Rather than diversifying their livelihood activities and income sources, people continue to rely exclusively on the exploitation of forest resources, thus subjecting those resources to constant stress and causing a drop in productivity and the collapse of stocks. In particular, communities are dependent both on bamboo and on forest species for agriculture and energy.

- Illegal hunting, which is a major threat to wildlife, is carried out not only to make up the dietary shortfall in animal protein but also for trafficking, particularly of elephant tusks, hippopotamus teeth and baby gorillas.

\section{Land use}

It is important to note that spatial planning is at a very early stage, and no forest concession exists. Nevertheless, two macro-zones can be identified in the Virunga landscape:

- $\quad$ Protected areas: Virunga National Park (designated a UNESCO World Heritage Site in 1979) and Volcanoes National Park (biosphere reserve) on one side of the landscape, and the Rutshuru Hunting Domain on the other side.

- Community-based resource management areas: Djuma, Mwenda and Bwisha in the Democratic Republic of the Congo and Kinigi-Burera in Rwanda.

The main land use activities are conservation (52\%), agriculture (45 \%) and fishing (3\%). Furthermore, artisanal mining, although not very extended, occupies $5 \%$ of the landscape and has a negative impact on the lives and activities of populations (Devers and Vande weghe 2007). 


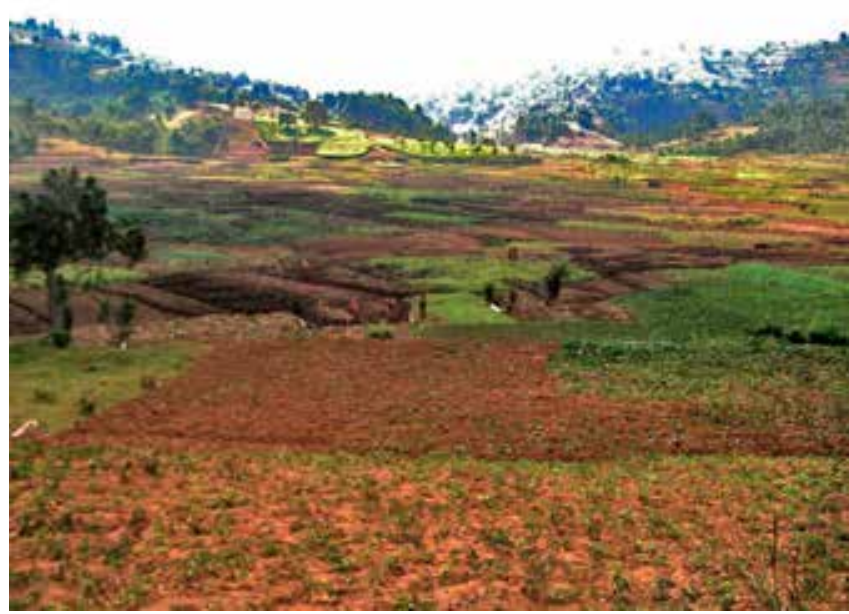

Methods of exploitation of valleys in the Virunga landscape (Source: Anne Marie Tiani)

\section{Institutional partners}

The main institutional partners in the Virunga landscape are:

- Institute in Congo for the Conservation of Nature (ICCN)

- Rwanda Development Board (RDB)

- Rwanda Natural Resources Authority (RNRA)

- African Wildlife Foundation (RNRA)

- University of Maryland Central Africa Regional Program for the Environment (UMD-CARPE)

- Observatoire Satellital des Forêts d'Afrique Centrale (OSFAC)

- $\quad$ African Forests (FORAF)

- International Union for the Conservation of Nature (IUCN)

- Tom Patterson, US National Park Service

- Fauna \& Flora International (FFI)

- World Wide Fund for Nature (WWF)

- Zoological Society of London (ZSL)

\section{Opportunities, adaptation and REDD+}

Some of the activities underway in the Virunga landscape focus on preserving forest and natural resources because of their importance for adaptation and mitigation. Following are some noteworthy projects

- Through community reforestation, an area of 600 ha has been reforested in the territories of Masisi, Rutshuru, Beni and Lubero (Ko 2011). The result is the progressive re-establishment of vegetation, creation of a sense of belonging among the local people involved and development of greater awareness among local people of the importance of protecting nature.

- By manufacturing briquettes, or stabilised soil blocks, participants can potentially earn up to US\$45 per month. This activity also helps to build adaptive capacity through income generation and to reduce soil erosion.
- $\quad$ The construction of fishponds in humid areas creates a supply of aquatic products, thus contributing to adaptive capacity by diversifying people's livelihoods, while protecting the rich marine biodiversity of the landscape.

- The Virunga environmental programme, which was established by WWF in 1987, is a long-term programme whose aim is to protect the Virunga ecosystem through the environmental education of managers and local people. It also aims to boost economic development and to create alternative energy sources in the landscape and its surrounding areas. These activities boost climate change resilience and facilitate the implementation of conservation projects such as REDD+.

- $\quad$ The installation and maintenance of water pumps enables the supply of local river water for people and livestock, thus reducing the risk of water shortages caused by climate changes.

- Subsidies given to communities allow them to undertake environmental conservation activities and to diversify their sources of revenue (e.g. creation of agricultural cooperatives, distribution of seeds, improvement of habitat), thus strengthening their resilience to climate change by endowing them with a wider range of financial assets.

- The development of tourism in the area creates a new source of income that can be used to benefit the management and conservation of the landscape.

- $\quad$ The domestication of non-timber forest products (e.g. bamboo, honey, mushrooms) and the introduction of agroforestry into rural zones around the protected areas strengthen adaptive capacity because these have been shown to be more resilient to climate variations.

- Support for the elaboration of forest plans by district authorities that could facilitate REDD+ processes.

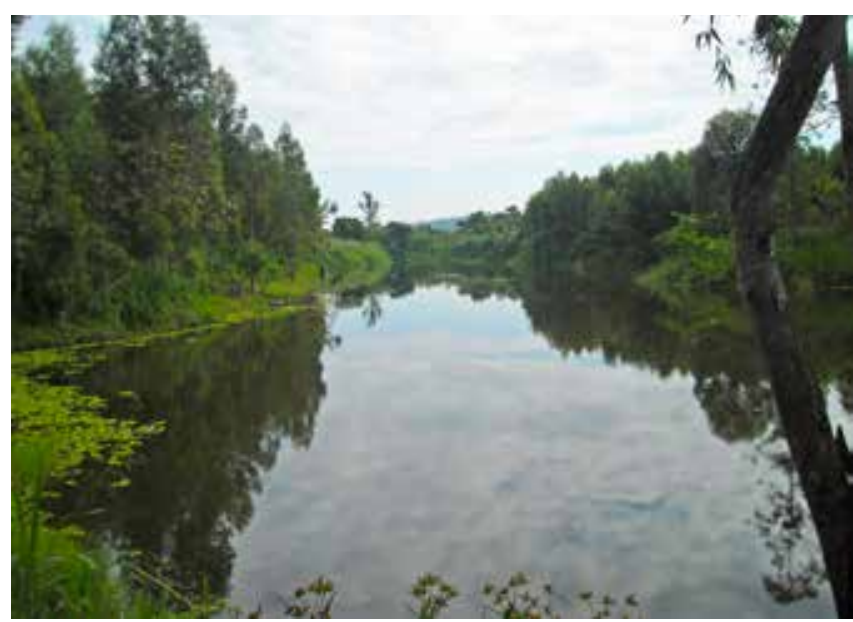

Fishpond built for subsistence fishing (Photo: Claude Sikubwabo) 


\section{Challenges and constraints for REDD + and adaptation}

The Virunga landscape is subject to multiple threats that will reduce its climate resilience and complicate efforts to implement REDD+:

- weak social capital because local people have not formed organisations and weak managerial skills of landscape managers (social capital is important for adaptation projects);

- $\quad$ social instability and insecurity in the landscape and its surrounding areas because of the influx of refugees and establishment of military camps;

- $\quad$ illegal mining in protected areas, hindering REDD+ interventions;

- uncontrolled industrial exploitation of wood;

- inadequate legal framework and lack of adaptation policies;

- inadequate human and financial resources for better landscape management, allowing overexploitation of natural resources to continue;

- inadequate tools for planning and sustainable landscape management;
- $\quad$ poor public participation in the management of protected areas, which could weaken REDD+ governance structures; and

- $\quad$ use of poor agricultural techniques, thus encouraging the expansion of agriculture (and therefore inducing deforestation) and reducing adaptive capacity of natural resources.

\section{Sources consulted}

Devers, D. and J.P. Vande weghe (eds). 2007. The forests of the Congo Basin - state of the forest 2006. Publications Office of the European Union, Luxembourg.

De Wasseige, C. and D. Devers (eds). 2009. The forests of the Congo Basin - state of the forest 2008. Publications Office of the European Union, Luxembourg.

De Wasseige, C. and D. Devers (eds). 2011. The forests of the Congo Basin - state of the forest 2010. Publications Office of the European Union, Luxembourg.

Ko, J. 2011. Rapport annuel 2012: Activités USAID/CARPE dans les paysages COMIFAC/PFBC à l'appui du plan de convergence de la COMIFAC (Septembre 2009-Septembre 2010)

Wengamulay, J. 2011. Paysage Virunga et le changement climatique. Presented at a workshop, Douala, 12-14 May.

This research was carried out by CIFOR as part of the CGIAR Research Program on Forests, Trees and Agroforestry. This collaborative program aims to enhance the management and use of forests, agroforestry and tree genetic resources across the landscape from forests to farms. CIFOR leads the program in partnership with Bioversity International, CIRAD (Centre de coopération internationale en recherche agronomique pour le développement), the International Center for Tropical Agriculture and the World Agroforestry Centre.
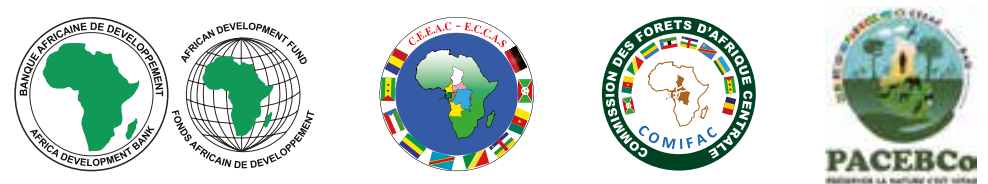

cifor.org/cobam 